\title{
ANALISA PENGARUH KEMAMPUAN KERJA PEGAWAI DAN KOMUNIKASI ANTAR PRIBADI TERHADAP KUALITAS PELAYANAN PERUSAHAAN PT. INDOSAT TBK
}

\author{
M. Ifran Sanni ${ }^{1}$ \\ Sendy Zul Friandi ${ }^{2}$ \\ Danang Rifai ${ }^{3}$ \\ Dosen AMIK Raharja Informatika ${ }^{1}$, Dosen STMIK Raharja ${ }^{2,3}$ \\ Jl. Jendral Sudirman No. 40, Modern Cikokol, Tangerang ${ }^{1,2,3}$ \\ Email : ifran@raharja.info ${ }^{I)}$, sendy@raharja.info ${ }^{2)}$, danang.rifai@raharja.info ${ }^{3)}$
}

\begin{abstract}
ABSTRAK
Menjawab tantangan dunia usaha pelayanan telekomunikasi dengan semakin tajamnya persaingan, indosat perlu melakukan peningkatan kualitas pelayanannya. Untuk itu perlu kajian yang serius terhadap faktor faktor yang mempunyai pengaruh terhadap kualitas pelayanan itu sendiri. Di duga kemampuan kerja pegawai dan komunikasi antar pribadi dapat berpengaruh pada kualitas pelayanan pada perusahaan ini Penelitian di lakukan dengan tujuan membuktikan dugaan bahwa kemampuan kerja pegawai dan komunikasi antar pribadi secara bersama - sama berpengaruh terhadap kualitas pelayanan pada Indosat. Dari hasil pengolahan data dapat di ketahui bahwa secara sendiri - sendiri kedua variable bebas masing masing memiliki hubungan dan pengaruh yang sama kuat terhadap kualitas pelayanan $(r X 1=0,621$ dan $r \times 2=0,670)$ Secara bersama - sama variable Kemampuan Kerja Pegawai dan Komunikasi Antar Pribadi Berhubungan sangat kuat dengan kualitas pelayanan pada $(R=0,853)$ dan berdasarkan hasil koefisien determinasi berpengaruh sebesar 72,8\% Hasil uji signifikan dengan uji $T$ dan uji $F$ terbukti signifikan pada taraf kepercayaan 95\%, maka dapat disimpulkan bahwa : Dugaan kemampukan Kerja Pegawai dan Komunikasi Antar Pribadi secara bersama-sama berpengaruh terhadap Kualitas pelayanan pada PT Indosat Tbk. Secara positif dan signifikan dapat di terima.
\end{abstract}

\begin{abstract}
Answering the challenges of the business world of telecommunications services with the sharpening of competition, Indosat need to do to improve the quality of service. For that we need a sober assessment of the factors that have an influence on the quality of the service itself. Suspected of employees working ability and interpersonal communication can affect the quality of service at the company experiment was conducted with the aim of proving allegations that an employee working ability and interpersonal communication together affect the quality of care in Indosat. From the results of data processing can be in the know that individually and the two independent variables have a relationship and influence equally strong on the quality of service ( $r X 1=0.621$ and $r \times 2=0.670)$ Collectively variable Job Skills Employees and Communication Between Personal Associated very strong with quality service on $(R=0.853)$ and by the coefficient of determination of $72.8 \%$ affect test results significantly with $T$ test and $F$ test proved significant at $95 \%$ confidence level, it can be concluded that: Alleged ability Employee Work and Inter-Personal Communication together effect on the quality of service at PT Indosat Tbk. Positive and significant effect can be received.
\end{abstract}

\section{PENDAHULUAN \\ Latar Belakang}

Beberapa tahun terakhir ini perusahaan yang bergerak di bidang layanan telekomunikasi di Indonesia semakin banyak. Persaingan yang kian ketat tidak dihindarkan lagi. Beberapa produk layanan yang inovatip di tawarkan dengan harga yang bersaing. Kondisi ini senantiasa 
mendorong perusahaan perusahaan di bidang ini untuk senantiasa meningkatkan kualitas pelayanannya.

Banyak hal yang dapat mempengaruhi kualitas pelayanan di antaranya adalah sumber daya manusia. Pelayanan yang berkualitas dapat tercipta apabila perusahaan di dukung oleh sumber daya manusia yang berkualitas agar tercapai tujuan perusahaan serta keberhasilan pelaksanaan tugas di indosat dalam sosok pegawai yang mampu berprestasi, memberikan hasil kerja yang bermutu tinggi, tepat guna dan berhasil.

Faktor lain yang patut di duga mempunyai pengaruh terhadap kualitas pelayanan adalah komunikasi antar pribadi. Komunikasi merupakan salah satu bagian yang penting dalam kehidupan kerja dalam terciptanya hubungan antar pribadi yang baik, saling di mengerti, kerjasama, dan pada akhirnya adalah kepuasan kerja.

\section{BATASAN MASALAH}

Untuk Menjaga kosistensi penelitian, maka permasalahan dalam penelitian ini di batasi hanya pada :

1. Pengaruh kemampuan kerja pegawai dan komunikasi antar pribadi terhadap kualitas pelayanan pada PT. Indosat TBK

2. Obyek penelitian adalah para pegawai PT. Indosat TBK.

\section{HIPOTESIS}

Hipotesis alternatif yang diajukan adalah Sebagai Berikut :

"Diduga kemampuan kerja pegawai dan komunikasi antar pribadi secara simultan berpengaruh secara positif dan signifikan terhadap kualitas kerja pada PT. Indosat TBK"

\section{KERANGKA PEMIKIRAN}

Dalam penelitian akan menguji pengaruh faktor - faktor kemampuan kerja dan komunikasi antar pribadi apabila kedua faktor tersebut di berlakukan masing - masing maupun secara bersamaan terhadap karyawan PT indosat TBK.

Dalam memberikan gambaran mengenai pokok pikiran pada penelitian secara skematis kerangka pemikiran penelitian sebagai berikut : 


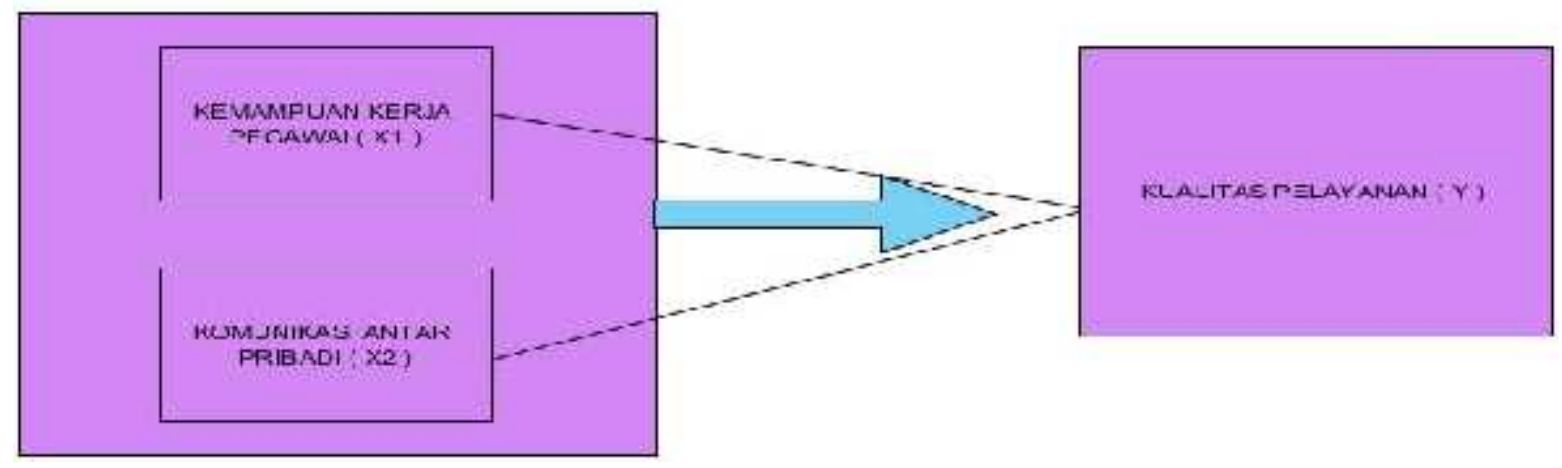

Gambar 1.1 Cart Skema Kerangka Pemikiran

Cart Skema kerangka pemikiran di atas menjelaskan sebagai berikut :

A. Variable - variable peneliti adalah :

Dalam penelitian inii menggunakan 2 ( dua ) variabel yaitu :

- Variabel bebas (X).

1. Kemampuan Kerja ( X1 ).

2. Komunikasi antar pribadi ( $\mathrm{X} 2$ ).

- Variabel terkait ( Y ) : Kualitas pelayanan.

B. Variabel x1 dan Variabel Y :

1. Mendapatkan gambaran apakah ada hubungan antara variable kemampuan kerja ( X1 ) dengan variable kualitas pelayanan ( Y ).

2. Mengetahui adanya pengaruh variable kemampuan kerja ( X1 ) terhadap variable kualitas kerja ( Y ).

C. Variabel X2 dan Variabel Y :

1. Mendapatkan gambaran apakah ada hubungan antara variable komunikasi antar pribadi ( X2 ) dengan variable kualitas pelayanan ( Y ).

2. Mengetahui adanya pengaruh komunikasi antar pribadi ( $\mathrm{X} 2$ ) terhadap kualitas pelayanan ( Y ).

D. Variabel X1, X2 dan Y

1. Mendapatkan gambaran adanya hubungan antara variable kemampuan kerja ( X1 ) dan komunikasi antar pribadi ( X2 ) secara simultan dengan variable kualitas pelayanan ( Y ) pada PT. Indosat TBK

2. Mengetahui adanya pengaruh variable kemampuan kerja ( $\mathrm{X} 1$ ) dan komunikasi antar pribadi ( X2 ) secara simultan terhadap variable kualitas pelayanan ( Y ) pada PT. Indosat TBK

\section{LITERATUR REVIEW}

Literature Review ini dilakukan oleh peneliti untuk mengetahui landasan awal dan sebagai pendukung bagi kegiatan penelitian yang dilakukan oleh peneliti, sehingga dapat 
menghindari pengulangan hal yang sama dalam penelitian dan dapat melakukan pengembangan ketingkat yang lebih tinggi dalam rangka menyempurnakan atau melengkapi penelitian yang nantinya di kembangkan lagi kedepannya.

Adapun Literature Review sebagai berikut :

1. Penelitian yang dilskuksn Lusyani Sunarya dkk. Yaitu Desain Media Sigin System dan Himbauan Sebagai Penunjang Informasi Pada Yayasan Islam Attaqwa.

2. Peneletian yang dilakukan oleh Hanif Hasan J. dkk. Yaitu. Analisis Investasi Saham Subsektor Properti dan Real Estate di Indonesia

3. Peneletian yang dilakukan oleh Siti Rafika Putri. Yaitu Pengaruh perilaku WPS dalam Pencarian Pengobatan PMS, Lingkungan dan Status Kesehatan Terhadap Kualitas Hidup WPS di Kelurahan Dadap Tangerang

4. Peneletian yang dilakukan oleh Rini Kundaryati. Dkk. Yaitu hubungan Antara pendidikan dan Sumber Informasi Dengan Tingkat Pengetahuan ibu Tentang Post Partum Blues di RB Ratna Komala Bekasi Jawa Barat.

5. Penelitian yang dilakukan Sendy Zul Friandi, yaitu Perancangan Media Absensi Berbasis Website dengan menggunakan Framework Yii.

\section{METODELOGI PENELITIAN}

Teknik analisa data yang digunakan untuk membuktikan hipotesis dengan gambaran adanya pengaruh variable - variable bebas terhadap variable terkait, maka yang akan di gunakan adalah statistik deskriptif dan inferensial ( parametris ).

Adapun rumusan yang digunakan dalam penelitian ini adalah sebagai berikut :

\section{Rumus Koefisien Korelasi ( Karl Pearson )}

$$
r-\quad \begin{gathered}
n \Sigma(X Y)-(\Sigma X)(\Sigma Y) \\
\sqrt{\left.\left(n X X^{-2}\right)-(\Sigma X)^{2}\right)\left(n\left(\Sigma X^{2}\right)-(\Sigma Y)^{2}\right)}
\end{gathered}
$$

Dimana :

$\mathrm{r}$ : Besarnya korelasi atau hubungan antara variable bebas $(\mathrm{x})$ dan variable terkait ( $\mathrm{Y}$ )

$\mathrm{X}$; Variabel bebas

Y ; Variabel terkait

$\mathrm{n}$; Jumlah responden

Hasil perhitungan korelasi menurut agus irianto dlam buku "statistic konsep dasar dan aplikasinya" ( $2004: 141)$ :

a. Korelasi Positif Kuat, apabila hasil perhitungan korelasi mendekati +1 atau sama dengan 1

b. Korelasi negative kuat, apabila hasil perhitungan korelasi mendekati - 1 atau sama dengan 1.

c. Tidak ada korelasi, apabila hasil perhitungan korelasi mendekati 0 atau sama dengan 0 . 


\section{Korelasi Ganda.}

Korelasi ganda seperti di kemukakan oleh sugiyono dalam buku "statistic untuk penelitian" ( $2002: 218$ ) adalah hubungan secara bersama - sama antara X1 degan X2 dan Xn dengan Y.

Kaitan dengan penelitian ini, hubungan antara variable - variable yang akan di ketahui kekuatan hubungannya secara bersama - sama ( simultan ) adalah Kemampuan kerja pegawai dan Komunikasi antar pribadi dengan Kualitas Pelayanan PT. Indosat Tbk.

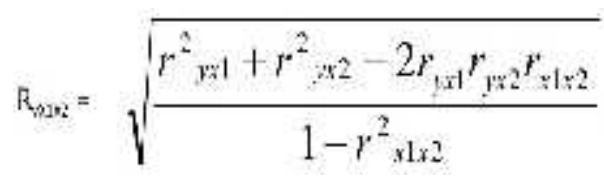

( Sugiyono, 2002: 218 )

Keterangan :

R.y.X1.x2 = Korelasi antara variable X1 dengan X2 secara bersama sama

r.yx $1=$ Korelasi antara X1 dengan $\mathrm{Y}$

r.yx2 $=$ Korelasi antara X2 dengan $\mathrm{Y}$

r.X1x2 = Korelasi antara X1 dengan X2

\section{Regresi Berganda}

Regresi berganda di gunakan untuk mengetahui pengaruh variable bebas X1 dan variable bebas X2 dalam penelitian kemampuan Kerja dan Komunikasi antar pribadi terhadap kualitas Pelayanan PT Indosat Tbk.

$$
\mathrm{Y}-\mathrm{a}+\mathrm{b}|\mathrm{X}|+\mathrm{b} 2 \mathrm{X} 2
$$

Dimana :

Y $\quad$ = Subyek dalam variable dependen yang diprediksi, yaitu Kualitas Pelayanan.

a $=$ Harga $\mathrm{Y}$ bila $\mathrm{X}=0$

$\mathrm{b}=$ angka arah atau koefisien regresi, yang menunjukan angka peningkatanatau penurunan variable dependen yang berdasarkan pada variable independen.

$\mathrm{X} \quad=$ Subyek pada variable independen yang mempunyai nilai tertentu, yaitu kemampuan Kerja ( X1) dan Komunikasi antar peribadi ( X2 )

\section{Uji Signifikan}

Untuk mengetauhi apakah analisa data berpengaruh secara signifikan maka perlu dilakukan uji hipotesis sebagai berikut :

a. $\quad$ Uji t (t-test)

Uji t untuk mengetahui taraf signifikan niali r. (korelasi sederhana), menggunakan rumus di bawah ini : 


$$
t_{\text {hitum }}=\frac{r \sqrt{(n-2)}}{\sqrt{\left(1-r^{2}\right)}}
$$

Dimana :

$\mathrm{t}$ hitung $\quad=$ disebut dengan distribusi student $\mathrm{t}$ ( diambil harga mutlaknya

)

$\mathrm{n} \quad=$ jumlah sampel

$\mathrm{r} \quad \quad=$ nilai koefisien korelasi

b. Untuk Regresi berganda

Persamaan regresi yang di dapat akan di uji apakah memang valid untuk memprediksi variable dependen.

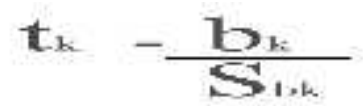

Dimana :

bk adalah koefisien regresi ke k dan Sbk adalah simpangan baku koefisien b yang ke $\mathrm{k}$

c. Uji F (ANOVA)

Untuk menguji signifikan koefisien korelasi ganda menurut sugiyono (2002 : 154) dihitung dengan rumus $\mathrm{F}$ di bawah ini :

$$
F=\frac{R^{\prime} / k}{\left(1-R^{2}\right) !(n-k-1)}
$$

Dimana :

$\mathrm{R}=$ koefisien korelasi ganda

$\mathrm{n}=$ jumlah pasangan observasi

$\mathrm{k}=$ jumlah variable bebas

dengan mempertimbangkan efisien waktu dan agar mendapatkan hasil penghitungan yang lebih akurat maka pada pemrosesan data akan di lakukan dengan menggunakan software statistic SPSS.

\section{Pedoman interprestasi Koefisien korelasi}

Dalam pedoman untuk memberikan suatu interprestasi yang di susun oleh sugiyono dalam buku "metode penelitian Administrasi" (2002; 149).

Tabel 1

Pedoman untuk memberikan interprestasi

\begin{tabular}{|c|c|}
\hline interval Koefisien & Tingkat Hubungan \\
\hline $0,00-0,199$ & Sangat Rendah \\
\hline $0,20-0,399$ & Rendah \\
\hline $0,40-0,599$ & Sedang \\
\hline $0,60-0,799$ & Kuat \\
\hline $0,80-1,000$ & Sangat Kuat \\
\hline
\end{tabular}


Pedoman di atas digunakan untuk mengetahui besarnya derajat atau kekuatan hubungan antara variable bebas dan variable terkait.

\section{OBJEK PENELITIAN}

PT. Indosat Tbk, sebelumnya di kenal sebagai PT. Indonesian Satellite Corporation Tbk (Persero) perusahaan salah satu penyedia layanan telekomunikasi terbesar di Indonesia yang di dirikan pada tahun 1967 sebagai perusahaan modal asing. Pada akhir tahun 2002 pemerintah Indonesia menjual 41,94\% saham indosat ke Singapore Technologies Telemedia Pte.Ltd

Dan di akhir tahun 2009 Qtel memiliki 65\% saham Indosat melalui tender offer ( memiliki tambahan 24,19\% saham seri B dari public).

\section{HASIL PENGUJIAN DAN PEMBAHASAN}

\section{Korelasi Sederhana ( Pearson Product moment)}

Pearson Product moment terkait dalam suatu penelitian rumus tersebut di gunakan untuk mengukur hubungan antar variable - variable di bawah ini :

- Kemampuan Kerja pegawai (X1)

- Komunikasi antar pribadi (X2)

- Kualitas pelayanan (Y)

Hasil pengolahan data menggunakan SPSS menghasilkan informasi sebagai berikut :

Tabel 2

Hasil Penghitungan Koefisien Korelasi

(Product moment / Karl Pearson)

\begin{tabular}{|c|c|c|c|c|}
\hline Nomor & Variabel & $\begin{array}{c}\text { Kualitas Pelayanan } \\
(\mathrm{Y})\end{array}$ & $\begin{array}{c}\text { Kemampuan } \\
\text { Kerja (X1) }\end{array}$ & $\begin{array}{c}\text { Komunikasi } \\
\text { antar pribadi } \\
(\mathrm{X} 2)\end{array}$ \\
\hline 1 & Kualitas pelayanan (Y) & 1,000 & 0,621 & 0,670 \\
2 & Kemampuan Kerja (X1) & 0,621 & 1,000 & 0,145 \\
3 & Komunikasi Antar Pribadi (X2) & 0,670 & 0,145 & 1,000 \\
\hline
\end{tabular}

Sumber : Hasil Pengolahan Data

Hasil penghitungan menunjukan bahwa :

- Koefisien antara variable kemampuan kerja pegawai dengan variable kualitas pelayanan menunjukan angka 0,621. Kedua variable tersebut memiliki hubungan yang positif dan kuat

- Koefisien korelasi antara variable komunikasi antar pribadi dengan variable kualitas pelayanan menunjukan angka 0,670. Kedua variable tersebut memiliki hubungan yang positif dan kuat

- Koefisien korelasi antara variable kemampuan kerja pegawai dengan variable komunikasi antar pribadi menunjukan angka 0,145. Kedua variable tersebut memiliki hubungan yang lemah 


\section{Koefisien Determinasi}

Untuk mengetahui pengaruh variable bebas terhadap variable terkait selanjutnya dapat dilakukan penghitungan nilai koefisien determinasi.

$$
\mathrm{KD}=(\mathrm{r} .)^{2} \times 100 \%
$$

Keterangan :

$\mathrm{KD}=$ Koefisien Penentu

r. $\quad=$ Koefisien Korelasi

dengan menggunakan rumus diatas maka diketahui bahwa :

- Kemampuan Kerja Pegawai (X1) dengan Kualitas pelayanan (Y) :

$\mathrm{R}^{2}=(0,621)^{2} \times 100 \%=38,5 \%$ angka tersebut menunjukan bahwa kualitas pelayanan di pengaruhi oleh kemampuan kerja pegawai sebesar 38,5\%.

- Komunikasi antar pribadi (X2) dengan Kualitas pelayanan (Y) :

$r^{2}=(0,670)^{2} \times 100 \%=44,9 \%$ angka tersebut menunjukan bahwa kualitas pelayanan di pengaruhi oleh komunikasi antar pribadi sebesar 44,9\%.

\section{Uji signifikan Koefisien korelasi}

Untuk mengetahui apakah hasil penghitungan tersebut dapat digeneralisasir pada populasi maka selanjutnya perlu dilakukan uji signifikan. Dalam penelitian ini menggunakan Uji t dan Uji f.

Tabel 3

Rangkuman Hasil Uji Signifikan dengan Uji t.

\begin{tabular}{|c|l|c|c|c|}
\hline Nomor & \multicolumn{1}{|c|}{ Korelasi Antara variabel } & t. hitung & t. tabel & signifikan \\
\hline 1 & $\begin{array}{l}\text { Kemampuan Kerja Pegawai (X1) } \\
\text { dengan kualitas Pelayanan (Y) }\end{array}$ & 7,795 & 1,99 & signifikan \\
\hline 2 & $\begin{array}{l}\text { Komunikasi antar Pribadi (X2) } \\
\text { dengan Kualitas pelayanan (Y) }\end{array}$ & 8,884 & 1,99 & signifikan \\
\hline
\end{tabular}

Sumber : Hasil Pengolahan Data

Rangkuman hasil uji t dalam table diatas menunjukan bahwa korelasi antara variable Kemampuan Kerja dengan Kualitas Pelayanan terbukti signifikan hal tersebut di tunjukan oleh hasil $\mathrm{t}$ hitung setelah dikonsultasikan $(\alpha=5 \% ; \mathrm{dk}=\mathrm{n}-2=97)$ yaitu $7,779>1,99$

Dan korelasi antara variable Komunikasi Antar pribadi dengan kualitas Pelayanan terbukti signifikan hal tersebut di tunjukan oleh hasil t hitung setelah dikonsultasikan $(\alpha=5 \% ; \mathrm{dk}=\mathrm{n}-2=97)$ yaitu $8,884>1,99$ 
Tabel 4

Rangkuman Hasil Uji Signifikan dengan Uji f.

\begin{tabular}{|l|l|l|l|}
\hline \multicolumn{1}{|c|}{ Model } & \multicolumn{1}{|c|}{ Jumlah Kwadrat } & \multicolumn{1}{|c|}{ Drajat kebebasan } & F hitung \\
\hline Regresi & 39,330 & 2 & 128,1685 \\
Residual & 14,1670 & 96 & \\
Total & 54,000 & 98 & \\
\hline
\end{tabular}

Sumber : Hasil Pengolahan Data

Tabel di atas menunjukan bahwa uji f yang dilakukan pada tingkat sognifikansi $(\alpha)=5 \%$, dan derajat kebesasan $=\mathrm{n}-1-\mathrm{k}$ atau $99-1-2=96$, menunjukan bahwa hasil penghitungan korelasi secara simultan antara variable Kemampuan Kerja Pegawai (X1) dan komunikasi antar pribadi (X2) dengan kualitas pelayanan (Y) terbukti signifikan.

Signifikan dapat di katakana apabila $\mathrm{F}$ hitung lebih besar dari $\mathrm{F}$ table, setelah di konsultasikan dengan $\mathrm{F}$ table $(\alpha=5 \%$; dk $=\mathrm{n}-1-2=96)$, ternyata lebih besar yaitu $128,685>3.09$.

Tabel 5

Koefisien Regresi Berganda

\begin{tabular}{|c|l|c|c|c|}
\hline Nomor & \multicolumn{1}{|c|}{ Variabel } & Beta & Std. eror & t. \\
\hline 1 & Konstanta & 5,842 & 2,317 & 2,552 \\
2 & Kemampuan Kerja Pegawai & 0,417 & 0,042 & 9,942 \\
3 & Komunikasi antar Pribadi & 0,498 & 0,45 & 11,013 \\
\hline
\end{tabular}

Sumber : Hasil Pengolahan Data

Dari hasil penghitungan regresi berganda di dalam table di atas maka persamaan Regresi Berganda adalah : Y = 5,842 + 0,417 X1 + 0,498 X2

Dimana :

$\mathrm{Y}=$ Kualitas pelayanan Perusahaan.

$\mathrm{X} 1$ = Kemampuan Kerja Pegawai.

$\mathrm{X} 2$ = Komunikasi antar Pribadi.

Nilai Konstanta sebesar 5,842 jika tidak ada faktor Kemampuan kerja dan Komunikasi pribadi, maka nilai kualitas adalah 5,84.

Nilai Kemampuan Kerja Pegawai (X1) sebesar 0,417 apabila faktor Kemampuan Kerja di tingkatkan satu kali maka akan terjadi kualitas sebesar 0,417.

Nilai komunikasi (X2) sebesar 0,498 menunjukan bahwa apabila faktor Komunikasi di tingkatkan satu kali maka aka nada peningkatan Kualitas pelayanan sebesar 0,498.

\section{Hasil Pembahasan Umum}

Hasil uji hipotesis menunjukan bahwa penelitian ini membuktikan beberapa hal yang mendukung hipotesis yang telah di bangun : 
1. Kemampuan Kerja pegawai dengan korelasi sederhana dapat di buktikan antara variable kemampuan kerja dengan kualitas pelayanan terbukti Positif dan Kuat, niali r yang di peroleh sebesar 0,621

2. Hasil pengukuran dengan koefisien determinasi kemampuan kerja pegawai mempengaruhi kualitas pelayanan perusahaan bernilai 38,5\%

3. Kemampuan kerja dan kualitas pelayanan Pengujian signifikan dengan uji $t$ menunjukan bahwa t hitung lebih besar dari t table ( 7,795 > 1,99). Membuktikan hasil penelitian tersebut digeneralisasi pada populasi atau hubungan dan pengaruh kemampuan kerja terhadap kualitas perusahaan tidak hanya berlaku pada sampel tetapi juga pada populasi.

4. Komunikasi antar pribadi dengan kualitas pelayanan hasil pengukuran dengan korelasi determinasi di ketahui bahwa komunikasi mempengaruhi pelayanan sebesar 44,9\%

5. Pengukuran dengan korelasi sederhana dapat di buktikan hubungan antara variable komunikasi dengan kualitas pelayanan perusahaan dinyatakan kuat dan positif niali $\mathrm{r}$ yang di peroleh sebesar 0,670

6. Komunikasi pribadi dan pelayanan Pengujian uji t menunjukan $(8,884>1,99)$. Ini membuktikan bahwa hasil penelitian dapat di generalisasikan pada populasi.

7. Hasil penghitungan koefisien regresi berganda menunjukan variable kemampuan kerja dan komunikasi terbukti valid signifikan dalam memberikan kontribusi terhadap variable

kualitas pelayanan menunjukan arah positif. Mengacu pada pembahasan umum di atas maka dapat di simpulkan bahwa hipotesis dalam penelitian ini yang berbunyi Kemampuan Kerja Pegawai dan Komunikasi Antar Pribadi secara simultan berpengaruh secara positif dan signifikan terhadap Pelayanan PT. Indosat Tbk.

\section{KESIMPULAN}

\section{Porses Pembuktian korelasi antar variable variable penelitian.}

Kemampuan kerja pegawai berkolerasi dengan Kualitas pelayanan perusahaan serta komunikasi antar pribadi dengan kualitas pelayanan perusahaan terdapat korelasi yang dapat di kategorikan kuat dan positif. Kemampuan kerja dan komunikasi secara simultan berkorelasi dengan kualitas pelayanan korelasinya dapat dikategorikan sangat kuat dan positif.

\section{Pengukuran dengan Koefisien determinasi maupun Kofisien Regresi}

Secara individual maupun secara simultan menunjukan kemampuan kerja dan Komunikasi pribadi berpengaruh terhadap kualitas pelayanan. Adapun pengaruh komunikasi terhadap kualitas lebih besar di banding dengan pengaruh kemampuan keja terhadap kualitas pelayanan perusahaan.

\section{SARAN SARAN}

Bagi peneliti berikutnya yang akan melakukan penelitian dengan topik sejenis disarankan hendaknya untuk menambahkan jumlah sampel yang digunakan. Selain itu variable lain yang belum dimasukkan kedalam penelitianini juga bisa digunakan contohnya : ukuran perusahaan (size) dan kebijakan perusahaan. Penelitian selanjutnya juga hendaknya mencoba menganalisa dengan sampel perusahaan yang heterogen. 


\section{DAFTAR PUSTAKA}

[1] Irianto Agus. Statistik : Konsep Dasar dan Aplikasinya. Prenada Media Jakarta. 2011

[2] Sugiyono. Metode penelitian Administrasi. Penerbit Alfabeta. Bandung 2015

[3] Suwarto, FX. Perilaku Keorganisasian. Penerbit Universitas Atma Jaya, Yogyakarta.2015

[4] Dahlan Siamat. 2011. Managemen Lembaga Keuangan Kebijakan Moneter dan Perbankan. Edisi ke lima. Jakarta : Fakultas Ekonomi Universitas Indonesia

[5] Samsul, 2012. Pasar Modal \& Manajemen Portofolio, Edisi Pertama. Jakarta : Erlangga

[6] Rahman, Harif. 2011. Pengaruh economic value added (EVA), return on asset (ROA), dan persentase kepemilkan modal saham asing terhadap harga saham pada perusahaan perbankan yang terdaftar di Bursa Efek Indonesia (BEI). Tesisdipublikasikan.Universitas Negeri Padang.

[7] Hakim, L., 2016 Epidemiologi Infeksi Menular Seksual. In Daili, S.F. et al., Infeksi Menular Seksual $4^{\text {th }}$ ed Jakarta: Balai penerbitan FKUI, 3-16

[8] Anwar, A 2010 Pengantar pendidikan kesehatan Jakarta PT Sasstra Hudaya 